\title{
Israel: Technical Note on Crisis Prevention and Management
}

This paper was prepared based on the information available at the time it was completed in April 2012. The views expressed in this document are those of the staff team and do not necessarily reflect the views of the government of Israel or the Executive Board of the IMF.

The policy of publication of staff reports and other documents by the IMF allows for the deletion of market-sensitive information.

Copies of this report are available to the public from

International Monetary Fund $\bullet$ Publication Services 700 19th Street, N.W. • Washington, D.C. 20431

Telephone: (202) 623-7430 • Telefax: (202) 623-7201

E-mail: publications@imf.org • Internet: http://www.imf.org

\section{International Monetary Fund Washington, D.C.}


FINANCIAL SECTOR ASSESSMENT PROGRAM UPDATE ISRAEL

CRisis PREVENTION AND MANAGEMENT TECHNICAL NOTE NOVEMBER 2012 


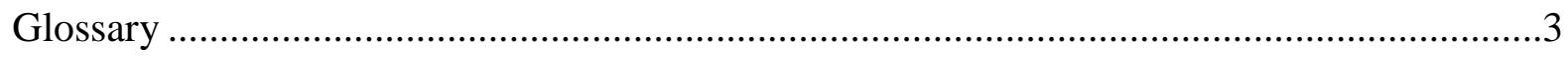

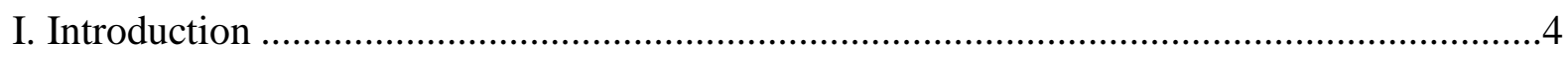

II. Legal and Institutional Arrangements for Macroprudential Oversight .............................5

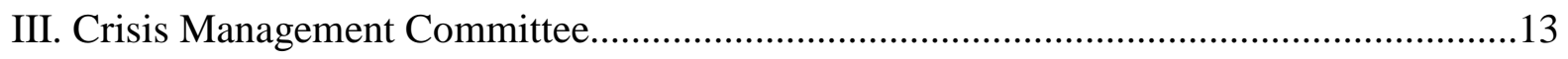

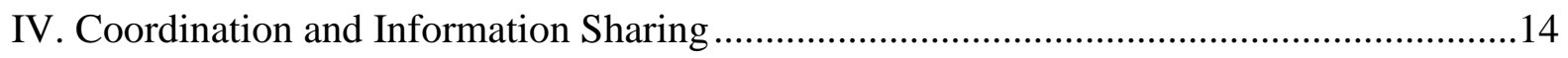

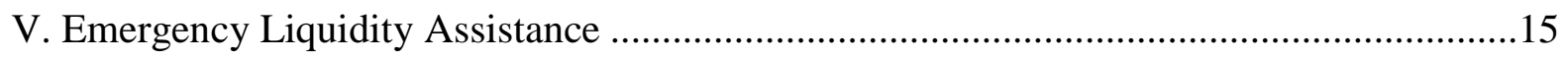

VI. Early Intervention and Orderly Resolution of Problem Banks .....................................17

VII. Solvency Support and Funding of Financial Firms in Resolution .............................21

VIII. Guarantees and Depositor Protection...................................................................23

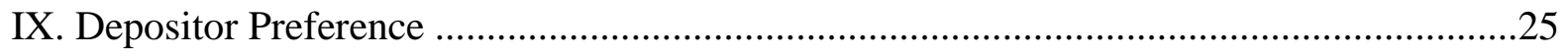

X. Early Intervention and Orderly Resolution of Problem Nonbank Financial Institutions ...26

TABLE

1. A Comparison of Alternative Arrangements for Depositor

Protection and Funding of Firms in Resolution ..........................................................26

\section{BOXES}

1. Elements to be Considered in Strengthening an ELA Framework in Israel .......................16

2. Possible Modalities of Resolution Fund ....................................................................22

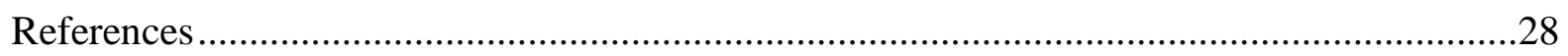




\section{GLOSSARY}

$\begin{array}{ll}\text { BOI } & \text { Bank of Israel } \\ \text { CMC } & \text { Crisis Management Committee } \\ \text { CMISD } & \text { Capital Markets, Insurance, and Savings Division } \\ \text { CCMIS } & \text { Commissioner for Capital Markets, Insurance and Savings } \\ \text { DGS } & \text { Deposit guarantee scheme } \\ \text { ELA } & \text { Emergency Liquidity Assistance } \\ \text { FSAP } & \text { Financial Sector Assessment Program } \\ \text { FSC } & \text { Financial Stability Committee } \\ \text { IAIS } & \text { International Association of Insurance Supervisors } \\ \text { IOSCO } & \text { International Organization of Securities Commission } \\ \text { ISA } & \text { Israel Securities Authority } \\ \text { LTS } & \text { Long-term savings } \\ \text { MOF } & \text { Ministry of finance } \\ \text { MOU } & \text { Memorandum of Understanding } \\ \text { NBFI } & \text { Nonbank financial institution } \\ \text { NIS } & \text { New Israeli shekel } \\ \text { P\&A } & \text { Purchase and Assumption } \\ \text { PCA } & \text { Prompt corrective action } \\ \text { TASE } & \text { Tel Aviv Stock Exchange } \\ \text { TBTF } & \text { Too-big-to-fail }\end{array}$




\section{INTRODUCTION ${ }^{1}$}

"Never say never"

1. Given the structure of the Israeli economy and financial system, many financial institutions are viewed as too-big-to-fail (TBTF). The level of concentration in both bank and non-bank financial sectors is high. The banking system is dominated by five banking groups, accounting for 95 percent of bank assets. In the insurance sector, the four largest groups have a dominant market share in most business lines (e.g., their share in the life insurance market is over 80 percent). Moreover, Israel's corporate sector is dominated by large conglomerates (the turnover of the six largest groups accounts for about a quarter of GDP), with strong links across sectors. While most of the large financial institutions in Israel came out of the recent global crisis relatively unscathed, the experience of other countries provided ample evidence of the importance of having a robust framework for identifying, mitigating and managing systemic risks. ${ }^{2}$

\section{A stronger macroprudential framework would help identify in advance, and} thus avoid or mitigate systemic financial threats. The aim of macroprudential oversight is to prevent rather than manage crises (which is the task of crisis management framework), and to focus on the whole financial system and systemic risks, rather than on individual institutions or financial sectors and idiosyncratic risks (which are the focus of prudential supervision). In the case of Israel, the current institutional set-up is designed mainly for micro-prudential and market conduct-related objectives, rather than to ensure well-focused macroprudential oversight and policy setting.

\section{The current juncture presents a good opportunity to strengthen the crisis} prevention capabilities and upgrade Israel's crisis management framework. A combination of fairly robust domestic financial conditions and a still fragile external environment provides an opportune time for taking steps towards establishing an effective framework for identifying and, where necessary, mitigating the build-up of systemic risks, as well as a framework for dealing with eventual problem financial institutions in a timely and effective manner in order to limit the impact of their distress on the financial system.

\section{4. "Best practice" in crisis management framework has been significantly} upgraded as a result of the recent crisis experiences. The "best practice" toolkit for dealing with financial institutions in resolution and liquidation includes the institutional

\footnotetext{
${ }^{1}$ This note was prepared by Anna Ilyina (MCM), Kotaro Ishi (EUR), Atilla Arda and Virginia Rutledge (both LEG) and has benefitted from comments by Jacek Osinski (MCM).

${ }^{2}$ See "Israel: Financial System Stability Assessment; IMF Country Report 12/69; March 12, 2012" for a discussion of Israel's experience and policies during the crisis.
} 
arrangements and a broad set of instruments for early intervention, official liquidity, and solvency support, as well as resolution of distressed financial institutions. In the case of Israel, several elements of such crisis management toolkits are either missing or have some weaknesses. More specifically:

- there is no formal emergency liquidity assistance (ELA) framework beyond the basic ELA provisions in the Bank of Israel (BOI) Law;

- the current provisions for early intervention powers in ailing financial institutions are limited;

- the range of resolution tools available to regulators is not sufficiently broad;

- the framework for coordination and information sharing between various supervisory authorities is not well-defined;

- there is no clear mechanism for funding of resolution; and

- there is no formal deposit guarantee scheme (DGS), but instead the BOI has the power (but not an obligation) to provide depositor and creditor protection in specific circumstances.

5. Bringing the financial crisis management framework in Israel in line with current best practice should result in a more appropriate sharing of costs associated with financial stress among the public, the financial sector, and creditors. Thus, better incentives would be provided for managing risk by financial institutions, while protecting the less financially sophisticated participants (depositors), and would ultimately reduce the public contingent liability for resolution of financial institutions or financial crises.

\section{Legal ANd InStitutional ArRangements For MaCroprudential OVersight}

\section{Main Conclusions and Recommendations:}

$>$ The current legal framework appears to imply that the BOI does systemic risk monitoring, assessment, and warning, and is expected to provide macroprudential policy advice to the government and the Knesset. Other regulators/supervisors lack substantial powers for macroprudential oversight.

$>$ The legal framework is not clear about how existing functions of relevant agencies could be utilized for macroprudential purposes. Coordination mechanisms are informally laid down in an MOU.

$>$ It is suggested, therefore, to establish more formally a standing national Financial Stability Committee (FSC) charged with macroprudential oversight. The FSC should be chaired by the BOI and in addition comprise all the relevant agencies, including the Ministry of Finance (MOF). 


\section{Conceptual framework}

6. Macroprudential policies seek to mitigate systemic risk (before such risk escalates in a crisis). In particular, macroprudential policies focus on three types of systemic risk:

- pro-cyclicality inherent in the financial system, as well as that generated by the real economy and microprudential oversight;

- failure of systemic institutions or systemic functions; and

- joint failure of financial institutions, markets or infrastructure due to their interconnectedness or similar type of exposures.

7. Macroprudential oversight should be distinguished from other financial policies that also contribute to financial stability. While macroprudential oversight concerns itself with the stability of the financial system as a whole:

- microprudential oversight aims primarily to maintain the soundness of individual institutions and/or to protect depositors and other consumers of financial services;

- consolidated supervision concerns itself with the soundness of financial groups and/or the risks an individual financial institution is incurring due to its membership of a financial group;

- oversight over payment and securities systems concerns itself with the soundness of individual systems;

- conduct of business supervision aims to ensure that financial markets are fair, efficient and transparent, and to protect investors and maintain their confidence in the financial system; and

- crisis management attempts to address a systemic crisis when one presents itself by, inter alia, mitigating the consequences of such crisis; it involves also crisis preparedness.

8. The following macroprudential functions can be identified:

- monitoring and assessing systemic risk;

- $\quad$ issuing systemic risk warnings;

- making macroprudential policy recommendations; and

- taking direct corrective regulatory, supervisory, and policy action.

9. Most, but not all, macroprudential tools are based on microprudential tools. An emerging consensus suggests that the following broad categories of tools could be utilized for macroprudential purposes (although they do not comprehensively address all systemic risks listed above): capital requirements, liquidity requirements, and requirements concerning business practices (e.g., loan-to-value-ratios and affordability ratios). For macroprudential objectives, the government and government agencies could utilize, for example, fiscal and tax policies, zoning and housing policies, and capital controls. Less agreement exists with 
respect to the use of monetary policy and capital control instruments for macroprudential purposes. Nonetheless, and without taking sides in the ongoing debate, this Note reviews whether legislation in Israel allows the use of monetary policy tools for macroprudential purposes.

10. Like any other public policy, macroprudential policies need to be supported by a sound legal framework. In the same vein, any public agency involved in macroprudential policies requires a legal mandate to do so because public entities - as creatures of statutecan only exercise authority that is vested in them by law. It also allows for establishing clear accountability mechanisms. For purposes of this Note, a mandate comprises a consistent set of objectives, functions, and powers and tools. Whether macroprudential policies are adequately anchored in law depends on the jurisdiction as a whole and not necessarily on the legal framework of any single public entity involved in such policies.

\section{The main legal test when assessing legal frameworks against the}

macroprudential framework outlined above is whether the law requires and/or allows that the risks of the financial system as a whole may be taken into considerations in the execution of functions and exercise of policy tools and legal powers, and whether legislation appropriately addresses all macroprudential functions.

Public entities and offices involved in monetary and prudential policies in Israel

\section{Three key public entities can be identified: the MOF (including the Capital} Markets, Insurance, and Savings Division (CMISD), the BOI (including the Supervisor of Banks), and the Israel Securities Authority (ISA). The Knesset is the legislator. Because the Israeli constitution is silent on the financial system and related policies and entities, ${ }^{3}$ there are no constitutional constraints in this regard on the design of legal/institutional framework for macroprudential policies in Israel.

\section{The Ministry of Finance is the key government office in charge of the capital} markets. The Minister either sets secondary legislation-sometimes with the approval of the Knesset Finance Committee — or the Minister approves rules proposed by the regulator.

14. Supervisory powers under the Insurance Law, the Payment System Law, and the Securities Law are vested in three regulators: the Commissioner for Capital Markets, Insurance and Savings in the MOF (CCMIS), the BOI, and the ISA.

\footnotetext{
${ }^{3}$ Israel does not have a single document entitled 'Constitution.' Instead, Israel's constitutional arrangements are laid down in so-called Basic Laws, which in some cases may require a supermajority to amend or overturn.
} 
15. Banking regulation and supervision is in the hands of the BOI Governor and the Supervisor of Banks appointed by the Governor. This follows from Section 4(7) of the BOI Law. See also Section 5 of the Banking Ordinance.

16. The BOI is also responsible for monetary policy and an orderly functioning of the foreign exchange market. (Section 4, BOI Law) Monetary policy decisions and decisions regarding management of foreign reserves and intervention in the foreign exchange market are taken by the Monetary Committee. ${ }^{4}$ (Section 15, BOI Law)

\section{For the purposes of macroprudential supervision, a Financial Stability Group} consisting of representatives from the three supervisory agencies was set up in mid2011. It is envisioned that the group will meet regularly and produce an internal report every quarter, providing an overview of macrofinancial stability issues together with policy options that will be discussed by the BOI's Monetary Policy Committee.

\section{Which agencies have a macroprudential mandate?}

18. None of the entities involved in monetary and prudential policies has a full, explicit macroprudential mandate. Such a mandate should include a statutory financial stability objective, ${ }^{5}$ macroprudential functions, ${ }^{6}$ and policy tools and legal powers to exercise these functions.

\section{Who has a statutory financial stability objective?}

19. The BOI is the only entity with a statutory financial stability objective. The BOI Law assigns the BOI several objectives: (Section 4) (i) a "central goal" to maintain price stability as determined by the government; (ii) a subordinated objective "to support other objectives of the Government's economic policy;" and-without indicating any hierarchy with the other two objectives - (iii) "to support the stability and orderly activity of the

\footnotetext{
${ }^{4}$ The Monetary Committee has broad authority to "determine policies" and "deciding actions under [the BOI Law]" for achieving the BOI's objectives."

${ }^{5}$ A financial stability objective could be absolute (e.g., "to maintain" or "to ensure") or relative (e.g., "to contribute to" or "to support").

${ }^{6}$ Macroprudential functions are described in paragraph 8.

${ }^{7}$ In addition to objectives under the heading "Objectives of the Bank," Section 4 on the "Function of the Bank" includes (intermediary) objectives for specific functions: the BOI's role in the foreign exchange market is "supporting the orderly activity" thereof; and oversight over payment and clearing systems is to "ensure their efficiency and stability." Sections 3 and 4 read in conjunction seem to suggest an indirect relationship between certain functions and the BOI's financial stability objective.
} 
financial system." (Section 3, BOI Law). Although the law does not explicitly indicate a hierarchy between the BOI's financial stability objective and its other objectives, from the structure of the law it follows that the financial stability objective is subordinate to the first.

\section{None of the other relevant public agencies or offices is explicitly mandated by legislation to ensure or to contribute to the stability of the financial system:}

- The MOF or the Minister has regulatory authority must follow the objective of relevant legislation related to the financial sector, which do not include financial stability objectives.

- CCIMS - Section 2.b of the Insurance Law provides that the Commissioner may issue instructions to insurers and insurance agents "in order to assure their orderly operation and the protection of the interests of insured persons or of clients, and in order to prevent any detraction from an insurer's ability to meet his obligations." In other words, the Commissioner exercises microprudential and conduct of business supervision

- ISA-Section 2 of the Securities Law provides that the ISA is to "protect the interests of the public investing in securities." Under the Securities Law, the ISA has a variety of responsibilities including licensing and supervising a range of market participants as well as overseeing the orderly conduct of the secondary markets. Ensuring orderly markets can be taken as a form of responsibility for one aspect of financial stability.

\section{Which agencies have responsibilities for macroprudential functions and relevant policy tools?}

21. The BOI is mandated to advice on macroprudential policies. Section 55(a) of the BOI Law requires the BOI to present the government and the Knesset Finance Committee, not less than twice annually, a report on the policies that the Monetary Committee believes necessary for the attainment of the BOI's financial stability objective. This requirement gives the BOI an opportunity to issue systemic risk warnings and implies that the BOI monitors and assesses systemic risks. Indeed, the BOI has broad information gathering powers. With a view to attain the BOI's objectives and discharge its functions Section 39 of the BOI Law gives the Governor access to all information from entities providing financial services, ${ }^{9}$

\footnotetext{
${ }^{8}$ The BOI's financial stability objective is appropriately limited to 'supporting' and not 'ensuring' financial stability because its jurisdiction, and that of its governor, the Supervisor of Banks, and the Monetary Committee, do not cover all financial institutions, markets, and infrastructure.

${ }^{9}$ The Monetary Committee has access to this information available to the Governor. (Section 30, BOI Law) The Insurance Law allows the Insurance Commissioner to share information with the Securities Authority and the Supervisor of Banks. (Section 50B) Section 13 of the Securities Law allows the ISA to share information at the discretion of the Chairman.
} 
whether they are supervised or not, either through a "Regulatory Authority" or — as a back-up authority-directly from the entities concerned. ${ }^{10}$

\section{Arguably, the BOI could exercise monetary policy also to limit systemic risks.}

The BOI Law does not link monetary policy directly to any of the BOI's objectives. In one instance, namely interventions in the foreign exchange market, the BOI Law suggests that such interventions can serve both monetary policy and financial stability objectives. (If an intervention is neither for administration of monetary policy nor to support the stability of the financial system, it generally requires the approval of the Minister of Finance.) Thus, it seems that the BOI could utilize its monetary policy powers also for its financial stability objective, albeit that its central goal is price stability as determined by the government. ${ }^{11}$

\section{The BOI's other main functions are not explicitly and directly linked to financial} stability. ${ }^{12}$ Although its responsibilities with respect to foreign currency markets, payment and clearing systems, and banking all would contribute to the BOI's objective to support the stability of the financial system, that does not mean that considerations based on the stability of the financial system as a whole and risks stemming from particular segments of the financial system that could threaten financial stability should or could be taken into consideration in the oversight over these segments. Nonetheless, in particular with respect to the payment and clearing systems oversight the BOI could decide that all such systems are systemic, de facto making this type of oversight subject to its financial stability objective.

\section{None of the other relevant agencies are mandated with macroprudential}

functions. Relevant legislation, however, seems not to prevent any of these agencies or offices from monitoring and assessing systemic risk, issuing systemic risk warnings, and making macroprudential policy recommendations to other agencies. Any entity involved would be limited by information available to it and applicable confidentiality rules. And although all involved have certain regulatory and supervisory authority, this authority can be used only for the purposes vested in them, which generally are not macroprudential purposes (see paragraph above). Notwithstanding the lack of full macroprudential mandate, each of the

\footnotetext{
${ }^{10}$ The BOI, through the Supervisor of Banks, has direct access to information from banks (Section 5(a), BOI Law).

${ }^{11}$ It should be noted, though, that from a legal perspective in some instances certain powers can serve financial stability purposes only in an indirect fashion. For example, although monetary policy in general could serve financial stability purposes, the Monetary Committee's decision on the interest rate "is set for the purposes of monetary policy." (Section 15.3, BOI Law). Consequently, it would seem that the interest rate policy tool can only be used for financial stability purposes after deciding that monetary policy in general will serve that purpose.

${ }^{12}$ Section 36(6) of the BOI Law allows the BOI to "take any other action the Bank deems necessary [to attain its objectives and discharge its functions] provided it obtains the approval of the [Monetary] Committee."
} 
financial regulatory agencies has information relevant for macroprudential oversight as well as policy tools that could be used for macroprudential purposes.

\section{Way forward}

\section{Can the current institutional set-up ensure a well-focused macroprudential} policy framework? The answer to this question depends on whether, under the current framework, the supervisory authorities have the incentives to share relevant information and analysis, and also have the ability to implement policies with an explicit financial stability objective. On balance, there seems to be a need to (a) formalize the importance of financial stability as a general public policy goal; (b) establish stronger mechanisms for on-going information-sharing; and (c) explicitly involve all relevant agencies in the process of monitoring systemic risks and making decisions on the policies to mitigate these risks; and (d) ensure for all relevant agencies that there is no legal impediment to using existing tools to implement those decisions.

26. It is suggested, therefore, to establish more formally a standing Financial Stability Committee (FSC) charged with macroprudential oversight. Options for achieving greater formality that would spell out the membership of the FSC, its objectives, and its mode of operation include establishing the FSC through an inter-agency MOU, a governmental decree or analogous instrument, or legislation passed by the Parliament. (Legislation could take the form of a new free-standing law or an amendment to existing law such as the BOI Law.) Any outstanding issues related to possible legal or other impediments for information-sharing or use of microprudential or other tools for macroprudential purposes should be dealt with during the process of establishing the FSC. This could be accomplished by amending the statutory mandates of the FSC's member agencies to include a clear objective "to contribute to or promote financial stability" (if necessary) and the legal authority to apply their regulatory powers for macroprudential purposes.

\section{The mandate and functions of the FSC should comprise the monitoring of} sources of systemic risk, and the establishment of a policy agenda to mitigate these risks. To ensure accountability, the framework should stipulate duties to communicate major policy decisions, and charge policy-makers with undertaking cost-benefit and risk analyses when deciding on actions to be taken. Joint publications such as a Financial Stability Report could be used as a vehicle for communication of key messages to the general public.

\section{The BOI is currently best positioned to play the leading role in macroprudential} supervision and policy setting. This is because the BOI (a) is currently the only agency with a statutory financial stability objective; (b) has the statutory role of economic advisor to the government and is mandated to advice on macroprudential policies; (c) is also the supervisor for the banking system, which is dominated by five banks, all of which are considered to be systemically important; (d) carries out an oversight of the payment and clearing system to 
"ensure their efficiency and stability" (Section 4 of the BOI Law); (e) has the power to access all information from entities providing financial services, including those that are under direct oversight of the ISA and CMISD; (f) provides emergency liquidity assistance (lender of last resort function) for both bank and nonbank financial intermediaries; (g) conducts macro stress tests; and (h) has already taken steps to build capacity for systemic risk monitoring and supervision (a special macroprudential unit has been set up for this purpose).

29. Other supervisory agencies have also made progress in establishing systemic risk monitoring frameworks for their respective sectors. ${ }^{13}$ The ISA attaches great importance to and has made progress towards establishing a framework for monitoring, mitigating and managing systemic risk, and aims at implementing the IOSCO principles regarding these matters. Furthermore, the ISA is an active member of the IOSCO Standing Committee on Risk and Research (SCRR), a committee which focuses on systemic risk aspects. The CMISD has continued to improve its stress-testing capacity, including the analysis of potential feedback effects from distress in insurance and pension funds into the rest of the financial system.

\section{All relevant financial regulatory agencies should be represented on the FSC.}

Given the arguments presented above, the BOI is best positioned to chair the FSC, which in addition, should include representatives from the ISA, CMISD, and the MOF. The BOI should have representatives for both monetary policy and banking sector stability. The MOF has a role because its policies affect macro-financial conditions; it controls instruments that may be used for macro-prudential purposes; and it needs to bear the fiscal burden in case of a crisis. The ISA should be included in the FSC because of its roles as securities regulator with regard to ensuring orderly markets, overseeing market infrastructures, "conduct of business" regulation, and regulator of collective investment schemes, all of which can contribute to monitoring, mitigating and managing systemic risk. The CMISD has a role because of its supervisory responsibilities for and information on the insurance and pension sectors (and its linkages with the rest of the system) that may be relevant for systemic risk assessment and mitigation. Organizationally, the FSC could be set up either as a dedicated committee related to the central bank (e.g., as in the U.K.) or as an independent committee. The FSC would not necessarily need to have a separate staff. Instead, its activities could be supported by the staff of the member agencies. If the BOI is the chair, then it could have the primary responsibility for supporting the FSC, but should be able to call on other agencies for staff with relevant expertise. Consideration could be given to the inclusion of external experts to counterbalance in-house views.

\footnotetext{
${ }^{13}$ In case of securities regulation, the IOSCO core principles adopted in 2008 specifically require that securities regulators should contribute to a process of monitoring, mitigating and managing systemic risk, appropriate to its mandate.
} 
31. The FSC should aim to work by consensus. ${ }^{14}$ If this would render the FSC indecisive, a more robust decision-making procedure should be put in place to ensure the FSC's effectiveness. The FSC's legal framework should also specify the consequences of any member agency's failure to comply with the FSC's decisions. One method would be to adopt a "comply or explain" rule. Under such rule, public accountability would reinforce the incentives for agencies to implement FSC decisions. The main disadvantage of such system is that it does not make the FSC decisions legally binding on the member agencies. An alternative would be to make the decisions of the FSC binding on the member agencies. Any decision-making procedure, however, should give due regard to both the political nature of the MOF, which is only accountable to parliament - hence the application of the comply-orexplain rule to agencies only — and the desired operational autonomy of the FSC's member agencies.

\section{The area of responsibility of the FSC should be clearly delineated vis-à-vis the} crisis management committee (discussed below). The make-up of these two committees will likely overlap significantly, but for the reasons given below, it seems necessary to establish two separate committees with clear and distinct mandates.

\section{Crisis Management Committee}

\section{Recommendation:}

$>$ Consideration should be given to establishing more formally a separate, standing "Crisis Management Committee" (CMC) charged with crisis preparedness and crisis management. ${ }^{15}$ The CMC should have representation from all the relevant agencies (i.e., those represented in FSC).

\section{The BOI has internal guidelines that set out the procedures for dealing with} weak/troubled banks. This procedure determines that information exchange and cooperation with other external parties will be done on a case-by-case basis, considering the nature of the problem and the impact of the specific bank's instability on the financial system. It also stipulates the establishment of a Steering Committee headed by the Supervisor of Banks with the authority to appoint other representatives to the committee. The list of pertinent members includes the finance minister, director general, and the comptroller of the finance ministry as well other regulators.

\footnotetext{
${ }^{14}$ See IMF Staff Discussion Note on "Institutional Models for Macroprudential Policy”, SDN/11/18 for a discussion of various considerations that affect the choice of the decision making mechanism of a financial stability committee.

${ }^{15}$ For instance, crisis management committee has been established in Turkey and is under consideration in a number of other countries.
} 
34. It can be helpful to have a coordinating committee that will be responsible for crisis preparedness activities during normal times, and for crisis management in the event a crisis develops. The functions of this committee are distinct from those of the FSC described above, whose functions are aimed at crisis prevention. Nonetheless, there will be substantial overlap among the agencies represented on the two committees. Hence, one may ask whether it would make sense to assign the two sets of responsibilities to two subcommittees of the same committee or to establish a mechanism for converting the FSC into a crisis management committee at the time a crisis develops. In the end, neither of these solutions seems fully workable. The former seems inadvisable in that the FSC will have an active policy-setting and implementation role, while the crisis management committee is more of a coordination mechanism for agencies. The latter is not workable because the crisis management committee will also have responsibilities for crisis preparedness activities during normal times. Furthermore, given the potential for fiscal costs associated with a crisis, the chair of the CMC should perhaps be the MOF rather than the central bank, at least once it is explicitly established that the MOF rather than the BOI bears this responsibility. However, the BOI may still be best placed to provide logistic and analytic support since much of the CMC's efforts will focus on banks and the payments and settlements system, where the BOI has the expertise, data, and supervisory responsibility.

\section{COORDINATION AND INFORMATION SHARING}

\section{Recommendation:}

$>$ Relevant institutions should have clear mandates and accountability. A coordination mechanism should be in place, including solid underpinnings for exchange of confidential information in crisis times.

35. Some information-sharing agreements are in place, but not necessarily tailored to what may be needed in crisis situations:

- Domestic arrangements: An MOU is currently signed between the BSD, ISA and the CMISD, but it is of general form and does not set specific arrangements in the case of a resolution or financial crisis. MOUs should be signed among key relevant agencies to define their respective roles and responsibilities, as well as cooperation (e.g., information sharing), in the event of a crisis.

- Cross-border arrangements: the BOI has signed MOUs with the U.S. Board of Federal Reserve System and the Federal Deposit Insurance Corporation on cooperation, but like the domestic MOUs, these address ongoing supervision rather than cooperation in times of crisis. The authorities are encouraged to follow international developments regarding 
the frameworks for effective cross-border resolutions (e.g., the FSB Key Attributes ${ }^{16}$ ) and take these developments into account in eventually revising their cross-border MOUs.

\section{EMERGENCY LIQUIDITY ASSISTANCE}

\section{Recommendation:}

$>$ Establish a formal framework for ELA, including eligibility requirements, solvency requirements, as well as policies on collateral, access limits, and interest rates charged for both banks and NBFIs that may be eligible to receive ELA support. The BOI should retain discretionary powers in providing ELA. Information sharing arrangements between the BOI and other supervisors should also be developed.

36. The new BOI Law has broadened the central bank's powers to provide ELA. Under the old law, the BOI was explicitly allowed to provide ELA only to banks, but now it is allowed to extend such support also to all non-bank financial institutions (NBFIs), such as provident fund, insurances, investment trust funds, portfolio managers, stock exchange members, and a clearinghouse (Article 36. (4) and (5)).

37. The current approach to providing ELA has potential drawbacks. The BOI Law does not stipulate the modalities for ELA lending. Rather, these specifics are left to the determination by the Monetary Committee, so that the committee can flexibly make ELA decisions on a case-by-case basis and for extraordinary events. The main drawback of this approach is that it could potentially open the door for the central bank to enter into quasi-fiscal operations, by providing long-term credit or risk-capital to a troubled financial institution. Furthermore, without a clear ELA framework, the central bank may face undue pressures during stress periods, particularly in the context where there is neither a financial institution resolution framework nor a safety net.

38. The mission recommends the establishment of a formal ELA policy framework. Principles governing the modalities of ELA assistance should include (a) solvency requirements; (b) coverage of eligible institutions; (c) collateral requirements; and (d) loan limits and maturity (see Box 1 for detailed recommendations). Following the enactment of the new BOI Law that explicitly allows the central bank to grant ELA to NBFIs, there is a pressing need to establish principles that determine which of the NBFIs may be eligible for ELA, what conditions are applied, and what safeguards-most importantly, information sharing and cooperation frameworks with other supervisors-should be in place. The framework should clearly establish that a decision to provide ELA rests with the BOI to ensure that it has flexibility to respond to unexpected developments.

\footnotetext{
${ }^{16}$ See, "Key Attributes of Effective Resolution Regimes for Financial Institutions", Financial Stability Board, October 2011.
} 


\section{Box 1. Elements to be Considered in Strengthening an ELA Framework in Israel}

Policies on ELA assistance vary among countries. However, many central banks indicate-in central bank legislation, regulations, or public speeches - that ELA would be granted with adequate collateral, only in exceptional circumstances, to a temporary illiquid but solvent institution with central bank holding discretionary power. The solvency requirement implies that the term "ELA" does not include capital support.

ELA arrangements should be part of an overall well-designed safety net, be supported by strong supervision and resolution frameworks, and ensure that private sector solutions are explored first.

Furthermore, close coordination between the BOI and the MOF should be required because, ultimately, any costs of ELA assistance, which may occur, will be borne by taxpayers. The BOI may also have to cooperate with the other regulatory agencies (the CMISD and ISA) that are responsible for nonbank institutions not supervised by the BOI.

Key principles on ELA to be considered-which should be agreed among relevant government agencies and publicly disclosed-are:

- Solvency requirements. For banks, ELA is only given to institutions judged to be technically solvent but temporary illiquid, to the best knowledge of the BOI Bank Supervisor. For non-bank financial institutions, relevant non-bank supervisors should have principal responsibility to assess solvency of a trouble financial institution and should be responsible to provide all required information to the BOI. In judging solvency issues, the supervisor also needs to take into account whether a troubled institution is viable going forward.

- $\quad$ Eligible institutions. For banks, all licensed deposit taking financial institutions would be eligible for ELA. For NBFIs, the authorities need to decide what their liquidity needs are and in which way they might trigger systemic event.

- Adequate collateral. ELA should be granted with adequate collateral to protect the central bank's balance sheet. Moreover, the use of collateral could impose more discipline on institutions requesting ELA.

- Collateral policies. For ELA operations, a broad range of assets, beyond those accepted under normal monetary operations, which meet BOI's criteria for adequate collateral, can be accepted. Collateral should have sufficient credit-worthiness and be relatively easily handled (e.g., transfer of collateral). The haircuts for the collateral must be established, taking account of credit, legal, and operational risks. A schedule of eligible collateral for ELA assistance should be developed and published.

- Limits. The total amount of eligible collateral (with value adjusted for haircuts), that is at the borrower's disposal constitutes a natural upper limit on access to ELA resources in additional to any other limits established by the central bank.

- Interest rates. Interest rates should normally be no less than the standing credit facility rate, and designed to avoid mispricing or subsidizing liquidity assistance. Nevertheless, in a system-wide emergency situation, the rate could be set even below the standing credit facility rate.

- Maturity. The maturity of ELA usually should be short term but enough to address underlying liquidity problems. The loan can be renewable, with appropriate supervisory conditions to prevent undue recurrent access to ELA.

- Supervisory follow up. A financial institution that accesses ELA should subsequently be subject to intensified monitoring, and its management should be requested to prepare and implement a plan to reduce the likelihood of future ELA use.

- Disclosure. The central banks should report, at least ex post, on actions to demonstrate consistency with principles and account for any use of public funds. The timing of the disclosure of ELA operations should take into account the fact that some information may be market sensitive. 


\section{EARly Intervention ANd ORderly Resolution of Problem Banks}

\section{Recommendations:}

$>$ Strengthen and enhance the power of the BOI to take early intervention measures by (a) providing more flexible grounds for requiring corrective measures; $(b)$ ensuring that the BOI may require banks to take specific affirmative actions to correct identified problems; and (c) broadening the list of other measures the BOI may impose on a bank.

$>$ Introduce a framework for going concern resolution that will authorize a broad range of resolution techniques that can contribute to financial stability, while limiting the costs of resolution.

$>$ Introduce a special liquidation regime for banks, which provides tools for a rapid transfer of either a portfolio of assets and liabilities or of shares in a single purpose subsidiary so as to ensure continuity of key functions by a bank, including transfers to a bridge bank.

39. The powers of the BOI should be broadened to provide an up-to-date framework for both early intervention and resolution. The broader toolkit of resolution techniques and a supporting framework that ensures its ability to act quickly in resolving problem banks in order to prevent contagion and to minimize disruption to the provision of key financial services. It is also important to have more flexibility in resolution to limit the costs of resolution.

40. An overall legal framework for dealing with problem banks should establish a logical progression of increasingly stringent and intrusive powers to deal with problems of increasing severity (from relatively minor issues of noncompliance to near-insolvency or insolvency and liquidation). It is, therefore, helpful to think of the framework with reference to three distinct stages: early intervention, going concern resolution, and gone concern resolution.

\section{Early intervention}

41. Early intervention tools are the general enforcement powers that authorize a supervisory authority to require an institution to address any violation of law or regulation or unsafe and unsound practice. ${ }^{17}$ Use of these powers does not require a finding that the institution is in danger of failure and the bank remains under the control of its shareholders, directors, and officers.

\footnotetext{
${ }^{17}$ Some jurisdictions bolster the enforcement powers by requiring various corrective measures that are automatically triggered at declining levels of capital adequacy, a framework referred to as prompt corrective action (PCA). The endpoint of the PCA is typically a requirement to initiate formal bank resolution proceedings when the capital adequacy levels fall below a certain critical point.
} 
42. The ordinary enforcement powers are stipulated in the Banking Ordinance sections 8A through $8 \mathrm{C}$. These powers should be strengthened in several respects:

- Section 8A should provide more flexible grounds for taking action against a bank by making it clear that the BOI can require a bank to correct any violation of the Banking Ordinance or any legally binding directive or rule there under or any unsafe or unsound practice. It should not be necessary to determine that the conduct is likely to impair the bank's ability to meet its obligations or the proper conduct of its business. The purpose of early intervention is to be able to require corrective actions before the problem conduct begins to seriously affect the condition of the bank.

- Providing more flexible grounds for taking action under section $8 \mathrm{~A}$ also makes sense if the current framework, which provides a second level of enforcement actions under section $8 \mathrm{C}$, is retained. It is preferable to be able to resolve problems in banks early and providing for two stages of enforcement would likely take time. Therefore, the grounds for action under section $8 \mathrm{~A}$ as the first stage should be as early as possible.

- The law should also make clear that a bank may be required by the BOI to take affirmative action to correct the identified problem, including both violations of law and unsound banking practices. Having the authority to generally demand that the bank correct the problem, even within a specified period, is not sufficient. The BOI should have explicit power to indicate the specific steps that are required.

\section{Section 8C provides a second stage of enforcement, when a bank fails to correct} problems under section $8 \mathrm{~A}$, or if necessary to prevent the bank from being unable to meet its obligations or from causing harm to customers or other stakeholders. In these cases, the BOI is explicitly authorized to restrict activities of the bank, prohibit payment of dividends and bonuses, and suspend or remove an officer or director. The specific actions that the BOI may take should be broadened, so that the Law authorizes the BOI explicitly to take actions that correlate to the specific difficulties of the bank. At a minimum, the list of specified actions should also include a catch-all phrase that authorizes the BOI to take any other action, or require the bank in question to take any other action, that it determines to be necessary or appropriate to ensure that the identified problem is corrected.

\section{Going concern resolution}

44. In addition to the early intervention powers, a bank resolution framework should also have bank resolution powers in going concern (official administration) cases. ${ }^{18} \mathrm{~A}$ going concern resolution is one in which the problem bank is not closed and may

\footnotetext{
${ }^{18}$ A number of countries have some form of pre-insolvency bank resolution in going concern. There are significant variations in its design and even in the terminology used to describe it. In this paper, we use the term
} 
continue to operate, but the bank is placed under official control and the administrator takes on the powers of management and shareholders. Official control of the bank at this stage is a key feature that distinguishes resolution from early intervention is that in the latter case. A bank in official control may be resolved in one of several ways, some of which will ultimately result in the closure of the bank, typically after a transfer of the good parts of its business to a healthy acquirer.

\section{The Banking Ordinance contains the beginnings of a pre-insolvency form of} resolution. Section $8 \mathrm{D}$ authorizes the appointment of an administrator to manage a bank. However, its powers to resolve the bank are quite limited. To bring the framework into better alignment with good practices for resolution frameworks, we recommend that the BOI focus on a number of key issues discussed below.

46. The Banking Ordinance, and especially the grounds for taking action in sections 8A, 8C, and 8D, should avoid blurring early intervention tools and resolution tools. This can be accomplished by ensuring that the triggers for action for each of the phases avoid overlap and form a coherent progression as the powers become more stringent or intrusive. For the initiation of administration, the grounds should allow appointment of an administrator before the bank is technically insolvent. For the appointment of an administrator, a combination of both qualitative and quantitative triggers (related to capital adequacy, leverage ratios, or liquidity requirements) would be ideal.

\section{The law should also make clear that the primary objective of official} administration is to contribute to the stability of the overall financial sector. Another key (but subordinate) goal of going concern resolution is to avoid the significant loss in value that typically occurs immediately upon official initiation of liquidation proceedings. As is the case in current law, the administrator should be appointed and dismissed by the BOI and not by the courts. The law could explicitly authorize that administrator could be an employee of the BOI.

48. The official administration framework should provide the administrator with a broad range of resolution techniques. These include (a) a merger with a healthy bank; (b) rapid recapitalization with or without existing shareholders; (c) conversion of subordinated debt to equity; (d) purchase and assumption (P\&A) transactions; or (e) other transfers of assets and liabilities of the failing institution. For purposes of both P\&A transactions and other transfers of assets and liabilities, the law should allow the administrator the discretion to determine which assets and which liabilities should be transferred, unlike current law which requires the transfer of all liabilities (see section $8 \mathrm{~F}(\mathrm{e})$ of the Banking Ordinance). The

\footnotetext{
"official administration." Other terms for this type of bank resolution authority are "temporary administration," "interim administration," "statutory management," or "conservatorship."
} 
P\&A transactions may also entail the use of a bridge bank, if/when an acquirer cannot be immediately found.

49. Consideration could also be given to including the power to restructure the debt of a bank in administration through haircuts and/or conversion to equity. Such a technique may be especially relevant for systemically important banks, because the legal entity continues to operate, but the stakeholders are made to absorb the losses in order to return the bank to viability. For all of these tools, the law should be drafted to provide maximum flexibility to the administrator, subject to BOI oversight as under current law.

\section{The basic tasks of the administrator should be to:}

- assess the financial situation of the bank;

- where necessary, to establish a new balance sheet reflecting a fair and true view of the financial situation;

- if appropriate, write down capital accordingly, and convert subordinated debt into capital as needed;

- where possible, design and implement a restructuring plan for the bank, subject to the BOI's approval; and

- in case restructuring is not an option, to prepare the bank for orderly liquidation.

\section{The supporting framework for administration should address a variety of}

matters. For example, it may be necessary to override specific legal obstacles to expeditious action for various resolution techniques, such as shareholder preemptive rights under the Companies law or consent of depositors or borrowers for the transfer of their deposits or loans to a healthy institution. Current law already authorizes a moratorium on bank liabilities, though the provision could be made more flexible. As another example, to facilitate transfers of the derivatives business of a bank, it may be appropriate to temporarily suspend the termination rights of counterparties of the bank that might have arisen as a result of the appointment of the administrator or related decisions.

52. The role of the judiciary ideally would be limited to ex post review of resolution decisions. It is advisable if possible to preclude any stays of actions by the BOI or the administrator pending the review. To permit them will undermine the goal of preserving financial stability by delaying the effect of the chosen resolution measures. Furthermore, the level of review should be limited to determining that the BOI and the administrator acted in accordance with the law and their decisions were reasonable.

\section{Gone concern resolution}

53. For the final stage for dealing with problem banks (insolvency and liquidation), the current good practice is to establish a special resolution regime for banks that 
encompasses liquidation as well as the going concern resolution described above. The primary rationale is that even in liquidation considerations of financial stability and continuity of financial services by the ailing institution should take precedence over other creditors' interest; general insolvency regimes do not typically allow for this. It is currently the case in Israel that banks are subject to liquidation under the general corporate insolvency law.

54. It is recommended the authorities consider incorporating liquidation into the resolution regime provided for in the Banking Ordinance. Key features of a liquidation regime should include:

- Express power to transfer to a third party subsets of assets, liabilities, and combined portfolios of both (i.e., P\&A transactions) in the case of actual insolvency before the completion of liquidation.

- The power to establish a "bridge bank" to exist under government ownership to acquire in a temporary capacity the assets, liabilities, and essential functions in the event that an appropriate third party acquirer is not available.

- Authority of the liquidator to organize rapid transfers of assets such as shares in single purpose vehicles of the failed bank charged with, for instance, information technology, and payment system services. In case those services would not be separately incorporated, the liquidator should have the power to transfer rapidly all relevant assets, contracts, and staff from the insolvent estate to a solvent acquirer so as to ensure continuity of those functions.

- Ex post judicial review so that the liquidation process is administratively handled rather than being a court-controlled process.

- Possibly depositor preference that gives depositors a higher claim against assets of the bank than other unsecured creditors (see Section IX).

\section{Solvency SuPPort ANd Funding OF FinANCIAL Firms In RESOLUTION}

\section{Recommendation:}

Establish flexible and legally robust framework for providing solvency support and facilitating resolution. This framework has to ensure the availability and the judicious use of resources, the ability to act quickly in times of crisis, and also limit moral hazard for the financial firms in normal times. 


\section{A robust resolution framework requires consideration of how resolutions will be}

funded (Box 2). The framework for official solvency support and temporary funding of resolutions should allow the authorities to take steps to improve the solvency of a problem institution rapidly and in a legally robust manner. These steps could include recapitalization, guarantees, and balance-sheet debt relief. Given the need to act quickly in order to avoid contagion, as well as the need to limit potential moral hazard problems, the framework for solvency support has to ensure both the ex ante availability and the judicious use of financial resources.

\section{Box 2. Possible Modalities of Resolution Fund}

A resolution fund can be set up in different ways (see "Financial Sector Taxation: the IMF Report to the G20 and Background Material," September 2010, for discussion of country experiences). The main issues that need to be considered are discussed below:

- The main income component of this fund could be a levy. The levy would be paid by all financial institutions above certain size limit, initially at a rate varying by type of financial institutions; it could subsequently be refined to reflect individual institutions' riskiness, contributions to systemic risk (reflecting their size, complexity and inter-connectedness), and, possibly, variations over time in overall risk of the financial system. Levies based on individual institutions' contributions to systemic risks are the ideal, because they would also provide incentives for financial institutions to change their behavior and reduce negative externalities caused by them. However, levies on this basis might be difficult to estimate.

- This levy could be charged ex ante or ex post (to recoup the costs of financial crisis), or a combination of both. As in the case of the DGS, ex post funding might have the advantage in systems with a few large players as it increases their incentives to monitor each other, but has a drawback of being potentially pro-cyclical.

- The size of the resolution fund could be determined based on estimated needs of providing bridge financing in resolution in past crises or on the overall fiscal costs of providing support to the financial system during the past crises, taking into account the availability of funding from other sources.

- A backstop in the form of government loans may be needed in the event the resources of the financial stability fund are not sufficient.

- Any use of the resolution fund should be predicated upon a close interaction between the MOF, which has responsibility for the fiscal policy aspects of the fund, and the BOI, which has responsible for financial sector stability and relevant implementation capacity.

- To minimize moral hazard, the resolution fund needs to be linked to a credible and effective resolution mechanism that allocates losses across different groups of stakeholders of a given financial institutions.

\section{Furthermore, additional resources may be needed to make payments to facilitate} certain types of resolutions. For example, it may be necessary to make payments to a healthy acquiring institution to facilitate a resolution such as a merger or a P\&A transaction, where the value of liabilities transferred exceeds the value of assets. Where sources of funding are needed to facilitate resolution, it is generally recommended that jurisdictions should have in place one or some of the following arrangements: (a) a privately-financed DGS which can help fund resolution so long as that is in the best interest of all insured depositor; (b) a resolution fund; or (c) a standing budgetary authorization (possibly subject to 
a cap). Arrangements under (b) or (c) might include a funding mechanism for possible ex post recovery from the industry of the costs of resolutions. It should be noted that only (b) and (c) could be used also for solvency support.

\section{Guarantees ANd Depositor Protection}

\section{Recommendations:}

$>$ The authority of the BOI to guarantee deposits is not an appropriate function of a central bank. Therefore, consideration should be given to amending the Banking Ordinance (Article 8K) and adopting an alternative arrangement for depositor protection.

57. The current legal framework (Banking Ordinance Section 8K) allows the BOI to guarantee public deposits, as well as other bank liabilities, with the approval of the government. Upon approval of the government, the governor of the BOI may authorize the BOI to guarantee the deposits and other liabilities of a problem bank if certain conditions (under Article 8D) are met. At the discretion of the governor, such guarantees can be provided in part or in full, limited or unlimited, on a conditional or unconditional basis. Moreover, the governor can provide full guarantee of all liabilities of the problem institution if he is of the opinion that it is in the public interest and it would enable the bank to continue the orderly conduct of business.

58. Based on the past experience, precedence and expectation have been established that depositors (and often other creditors) are typically bailed out. In the 1983 banking crisis, depositors did not suffer losses, as the banking system was taken over by the government and no bank was allowed to fail. Since 1983, Israel did not experience any major bank failures, and depositors continued generally to be bailed out even in the cases of small bank failures (as in the 2002 episodes). While there were no bank failures during the recent global crisis, the MOF and the BOI issued statements assuring the public that the government would stand behind the stability of the financial system and that the BOI would use all tool available to protect depositors.

\section{The provision of deposit guarantees (or indeed guarantees of any bank}

liabilities) should not be the role of a central bank but rather the government. Such authority puts the balance sheet of the central bank at risk and can undermine its ability to conduct monetary policy. The only direct financial contribution of a central bank to crisis management should be the availability of ELA. Any other expenditures necessary to resolve a single institution or a systemic crisis should be the responsibility of the fiscal authority or the industry or both. For this reason, we recommend that section $8 \mathrm{~K}$ be repealed or, as an alternative, that it be revised to authorize the government to provide the guarantees, in consultation with the BOI. 
60. That said, the authorities will need to decide the appropriate level and explicitness of depositor protection that should be provided within the banking system in Israel and the appropriate mechanisms for doing so. There are recurrent debates in Israel on the need for a formal DGS. The main objectives of a DGS are to contribute to the stability of a financial system (by preventing panic withdrawals of bank deposits or by providing funding for certain types of resolution tools) and to protect less financially sophisticated depositors from the loss of deposits if a bank fails. Furthermore, the DGS is supposed to contribute to creating the level-playing field between the large and the small banks.

\section{There are a number of arguments that could be used against introducing formal} DGS in Israel:

- the current system seems to have worked well so far;

- the DGS may not be able to cope with failures of large and complex banks and hence, is less relevant in the Israeli context, given its highly concentrated banking system;

- any DGS would be viewed as providing a more limited protection than the current blanket (albeit informal) guarantee and if introduced in crisis or near-crisis time, could even cause panic;

- determining an appropriate reserve level may be difficult, and building up the reserve through assessments on banks will take time; and

- it may be difficult to calculate the risk-adjusted premiums that should ideally be charged to the banks.

\section{On the other hand, the absence of a formal DGS presents several risks:}

- because there is essentially no legally binding obligation to protect depositors, there may be circumstances under which the BOI's discretion to provide such guarantees may not be sufficient to stem deposit runs. Furthermore, external investors would not view uninsured deposits as being as "safe" as a source of funding as formally insured deposits (e.g., under Basel III, the insured deposits are treated differently from uninsured deposits for the purposes of calculations of the liquidity requirements);

- to the extent that there is a common belief that all depositors will always be bailed out simply because banks are TBTF, incentives for large depositors (as well as other types of creditors) to monitor the banks are reduced and incentives for banks to take on excessive risks are increased; and

- the current arrangement exposes the BOI and the MOF to potentially very large, but illdefined contingent liability.

63. Therefore, the value of a formal DGS (or alternative forms of depositor protection) should be kept under review. Possible depositor protection mechanisms 
include the following, some of which could be combined for more forceful depositor protection and for facilitating resolutions as discussed above:

- a formal DGS that would ensure retail depositors quick access to their deposits.

- depositor preference (See Section IX for details);

- a resolution fund that incorporates an ex ante funded (segregated) account to be used only for protecting depositors in the sense of a traditional DGS; or

- a resolution fund that provides that any use of funds must ensure protection of retail depositors.

\section{Depositor Preference}

64. A depositor preference gives some or all depositors a higher claim against assets of the bank than other unsecured creditors. Though such a preference has direct effect only in liquidation, there are several benefits to its introduction. Depositors can be sure of receiving their funds eventually so long as a failed bank is not so insolvent that its assets are less than its deposit liabilities. Hence, the depositors are less likely to "run" if they believe that the value of bank assets exceeds the value of its deposit liabilities. In countries with deposit insurance, adding a depositor preference provides a mechanism for reducing the losses of the DGS if the DGS is granted the same priority that the insured depositors would have had. Where the DGS has expended funds for their benefit, the DGS will then have a prior claim against the assets of the failed bank.

\section{Whether or not a jurisdiction has deposit insurance, a depositor preference} simplifies the use P\&A transactions by creating an inequality between the depositors eligible for the preference and other senior creditors. The inequality can justify transferring deposit liabilities and good assets via the P\&A while leaving other creditors behind with claims against the remaining assets of the failed bank. Also, in jurisdictions such as Israel that do not have an explicit DGS, depositor preference can provide a basis for providing early liquidation distributions to some or all depositors.

66. The table below compares some aspects of a formal DGS with a combination of resolution fund and depositor preference in terms of their capacity to provide depositor protection and contribute to safeguarding financial stability. A combination of resolution fund with depositor preference (but no DGS) provides greater flexibility in facilitating solvency support, as well as resolution for banks (and possibly, for NBFIs), while a formal DGS offers better protection to insured depositors. 


\section{Table 1. A Comparison of Alternative Arrangements for Depositor Protection and Funding of Firms in Resolution}

\begin{tabular}{|c|c|c|}
\hline \multirow[t]{2}{*}{ Objectives } & \multicolumn{2}{|c|}{ Possible Arrangements } \\
\hline & $\begin{array}{c}\text { Deposit Guarantee Scheme } \\
\text { (DGS) }\end{array}$ & $\begin{array}{c}\text { Resolution Fund } \\
+ \text { depositor preference }\end{array}$ \\
\hline $\begin{array}{l}\text { How much protection is } \\
\text { provided to depositors? }\end{array}$ & $\begin{array}{l}\text { (Possibly) full protection to } \\
\text { insured depositors }\end{array}$ & $\begin{array}{c}\text { Full to partial protection to all } \\
\text { depositors, conditional on recovery } \\
\text { value in liquidation }\end{array}$ \\
\hline $\begin{array}{l}\text { Does it help to reduce the } \\
\text { risk of failure of a } \\
\text { financial institution? }\end{array}$ & $\begin{array}{l}\text { Yes, by reducing the probability } \\
\text { of panic deposit withdrawals }\end{array}$ & $\begin{array}{c}\text { Yes, by reducing the probability of } \\
\text { panic deposit withdrawals (perhaps } \\
\text { to a lesser extent than the DGS) }\end{array}$ \\
\hline $\begin{array}{l}\text { Does it provide for } \\
\text { (1) immediate access of } \\
\text { depositors to their } \\
\text { accounts; } \\
\text { (2) full access (up to the } \\
\text { pre-specified limit) of } \\
\text { depositors to their } \\
\text { accounts? }\end{array}$ & $\begin{array}{l}\text { Yes, depending o } \\
\text { payout mechanis } \\
\text { (2) Yes }\end{array}$ & $\begin{array}{l}\text { (1) Not always } \\
\text { (2) Not always }\end{array}$ \\
\hline $\begin{array}{l}\text { Does it facilitate the use } \\
\text { of specific resolution } \\
\text { tools, e.g., } \\
\text { (1) P\&A transactions } \\
\text { (2) solvency support? }\end{array}$ & (2) No & $\begin{array}{l}\text { (1) Yes } \\
\text { (2) Yes }\end{array}$ \\
\hline $\begin{array}{l}\text { Does this arrangement } \\
\text { apply to both banks and } \\
\text { non-bank financial } \\
\text { institutions? }\end{array}$ & $\begin{array}{l}\text { No, only deposit taking } \\
\text { institutions }\end{array}$ & Yes \\
\hline
\end{tabular}

\section{Early Intervention ANd ORderly Resolution of Problem Nonbank FINANCIAL INSTITUTIONS}

67. While current framework may be adequate for most NBFIs, a special resolution framework may be needed for those that are "systemically important." Existing legislation for the nonbank sectors provides the supervisors with appropriate powers to take early corrective or enforcement actions, consistent with the applicable international standards. As for orderly resolution, because failures in these sectors have not tended to be time-sensitive, insolvency is handled under the general corporate insolvency framework. However, in the case of some NBFIs (for example, a clearinghouse) standard resolution tools may not be appropriate. One approach that may be considered for Israel, once the bank resolution framework has been fully developed, would be to provide that this framework may be applied to systemically-important NBFIs, if appropriate, at the time of their financial distress, and to also stipulate how this determination is to be made. 
68. The authorities should also follow reforms adopted in key jurisdictions with regard to resolution regimes for systemically important NBFIs and consider their potential applicability in Israel as the financial sector continues to develop. For example, the U.S. has adopted an orderly resolution regime for systemically important NBFIs of any type that is similar to the regime that applies to banks. In contrast, the U.K. has adopted separate special regimes for systemically-important banks and investment banks. 


\section{REFERENCES}

Erlend W. Nier, Jacek Osiński, Luis I. Jácome, and Pamela Madrid, 2011, "Institutional Models for Macroprudential Policy”, IMF Staff Discussion, SDN/11/18, November (Washington: International Monetary Fund).

Financial Stability Board, 2011, "Key Attributes of Effective Resolution Regimes for Financial Institutions" October.

International Monetary Fund, 2012, “Israel: Financial System Stability Assessment; IMF Country Report 12/69 (Washington: International Monetary Fund).

Stijn Claessens, Michael Keen, and Ceyla Pazarbasioglu, 2010, "Financial Sector Taxation: the IMF Report to the G20 and Background Material," September (Washington: International Monetary Fund).

Bank of Israel Law, 2010.

The Securities Law, 1968.

Banking Ordinance, 1941. 